\title{
Diel vertical migration and spatial overlap between fish larvae and zooplankton in two tropical lakes, Brazil
}

\author{
Picapedra, PHS. ${ }^{a *}$, Lansac-Tôha, FA. ${ }^{a, b}$ and Bialetzki, . $^{b}$ \\ aPrograma de Pós-Graduação em Biologia Comparada, Universidade Estadual de Maringá - UEM, \\ Av. Colombo, 5790, CEP 87020-900, Maringá, PR, Brazil \\ bPrograma de Pós-Graduação em Ecologia de Ambientes Aquáticos Continentais, Núcleo de Pesquisas em Limnologia \\ Ictiologia e Aquicultura, Departamento de Biologia, Universidade Estadual de Maringá- UEM, Av. Colombo, 5790, \\ CEP 87020-900, Maringá, PR, Brazil \\ *e-mail: Pablo_picapedra@hotmail.com
}

Received: July 25, 2013 - Accepted: February 6, 2014 - Distributed: May 31, 2015

(With 6 figures)

\begin{abstract}
The effect of fish larvae on the diel vertical migration of the zooplankton community was investigated in two tropical lakes, Finado Raimundo and Pintado lakes, Mato Grosso do Sul State, Brazil. Nocturnal and diurnal samplings were conducted in the limnetic region of each lake for 10 consecutive months from April 2008 to January 2009. The zooplankton community presented a wide range of responses to the predation pressure exerted by fish larvae in both environments, while fish larvae showed a typical pattern of normal diel vertical migration. Our results also demonstrated that the diel vertical migration is an important behaviour to avoid predation, since it reduces the spatial overlap between prey and potential predator, thus supporting the hypothesis that vertical migration is a defence mechanism against predation.
\end{abstract}

Keywords: diel vertical migration, spatial overlap, fish larvae, zooplankton, ecological interactions.

\section{Migração vertical diária e sobreposição espacial entre larvas de peixes e zooplâncton em dois lagos tropicais, Brasil}

\begin{abstract}
Resumo
O efeito de larvas de peixes sobre a distribuição vertical dia-noite da comunidade zooplanctônica foi investigada em duas lagoas tropicais, lagoa Finado Raimundo e Pintado, Mato Grosso do Sul, Brasil. Foram realizadas amostragens noturnas e diurnas na região limnética de cada lagoa durante um período de 10 meses consecutivos, entre abril de 2008 a janeiro de 2009. A comunidade zooplanctônica apresentou uma variada gama de respostas à pressão de predação exercida pelas larvas de peixes nos dois ambientes, enquanto que as larvas de peixes exibiram um padrão típico de migração vertical diária normal. Os resultados mostraram ainda, que a migração vertical diária é um comportamento importante para evitar a predação, uma vez que diminuiu a sobreposição espacial entre presa e seu predador em potencial, dando suporte a hipótese de que a migração vertical é um mecanismo de defesa contra a predação.
\end{abstract}

Palavras-chave: migração vertical diária, sobreposição espacial, larvas de peixes, zooplâncton, interações ecológicas.

\section{Introduction}

The diel vertical migration (DVM) of zooplankton is considered the largest (in terms of biomass) and the most regular migratory movement on the planet (Hansson et al., 2007a). The normal DVM is by far the most frequently observed pattern carried out by migrant zooplankton in marine and freshwater habitats (Pearre Junior, 2003). In the typical DVM behaviour, also referred as normal DVM, zooplankton remains in the upper strata during the night, and migrates toward colder and darker layers during the day (Wetzel, 2001). The most accepted hypothesis to explain the DVM is the avoidance of predation and argues that this ubiquitous behaviour pattern enables avoidance of visual predation by zooplankton in surface water through the use of deeper layers of the water column as a refuge during the day (Zaret and Suffern, 1976; Hansson et al., 2007b). This phenomenon has been a major subject in studies over the past decades (Ringelberg, 2010).

In plankton communities, predation risk of a given type of prey can be estimated from two primary components: the vulnerability of the prey and the density risk, which depend on the density of the predator and the spatial and temporal overlap between populations of predators and prey in nature (Williamson and Stoeckel, 1990). Prey-predator interactions are therefore strongly dependent on the spatial 
distribution of predator and prey, and DVM could be an effective mechanism to minimise the risk of predation by tactile and visual predators (Williamson, 1993).

Fish larvae play a key role in structuring the zooplankton community by selectively feeding on large-sized zooplankton, which leads to a change in the structure of the planktonic community, with the gradual development of dominance of small-sized species (Soares, 2003). Cushing (1975) suggested that the reproductive period, survival and growth of fish larvae are strictly dependent on periods of high food availability. This indicates that the investigation on the relationships between fish larvae and zooplankton is essential for the understanding of the distribution of organisms. The zooplankton community is heterogeneous in time and space, which could contribute to the variation in the fish larvae community.

Studies performed in the region of the Upper Paraná River floodplain related to the vertical distribution of zooplankton community are limited to very few studies, such as Tomm et al. (1992) and Lansac-Tôha et al. (1995), whereas studies on the vertical distribution of ichthyoplankton community are lacking, and studies relating both communities are restricted to those investigating the feeding of fish larvae, including Makrakis et al. (2005; 2008) and Manetta et al. (2011). According to Mehner (2012), there is no recent literature available regarding the mechanisms of DVM in freshwater fish. The existing DVM studies on fish are currently restricted to marine environments and only a few encompass in detail the historical reasons of the studies on DVM and its possible causes. Despite being widely proven that zooplankton may change its migratory behaviour in response to the presence of predators (Dodson, 1988), studies on diel vertical migration of zooplankton in nature, focusing on the prey-predator spatial overlap, are still scarce.

Thus the present study aimed to investigate the effect of fish larvae on the diel vertical distribution of the zooplankton community in the lakes Finado Raimundo and Pintado, which are permanent lakes located at the Ivinheima River basin in the Upper Paraná River floodplain. It was examined the changes in the spatial overlap between potential predator and prey, and verified the relationship of some environmental variables with densities of communities involved in this study.

\section{Material and Methods}

\subsection{Study site}

The Ivinheima River basin, one of the major tributaries of the right bank of the Paraná River, with an area of $38.200 \mathrm{~km}^{2}$ located in the state of Mato Grosso do Sul. The river course extends for about $310 \mathrm{~km}$, and the upper and middle stretches run in a north-south direction and the lower stretch runs parallel to the Paraná River (northeast-southwest direction), resulting in a large number of temporary and permanent lakes, some with a large size and with direct connections with the river (Souza-Filho and Stevaux, 2004).

For this work, we studied the lakes Finado Raimundo (P1) (22 47'40"S; 53 32'14'O) and Pintado (P2) (22 $56^{\prime} 46^{\prime \prime}$; 5 53 $\left.38^{\prime} 33^{\prime \prime} \mathrm{O}\right)$, which are permanently connected with the Ivinheima River (Figure 1). The margins

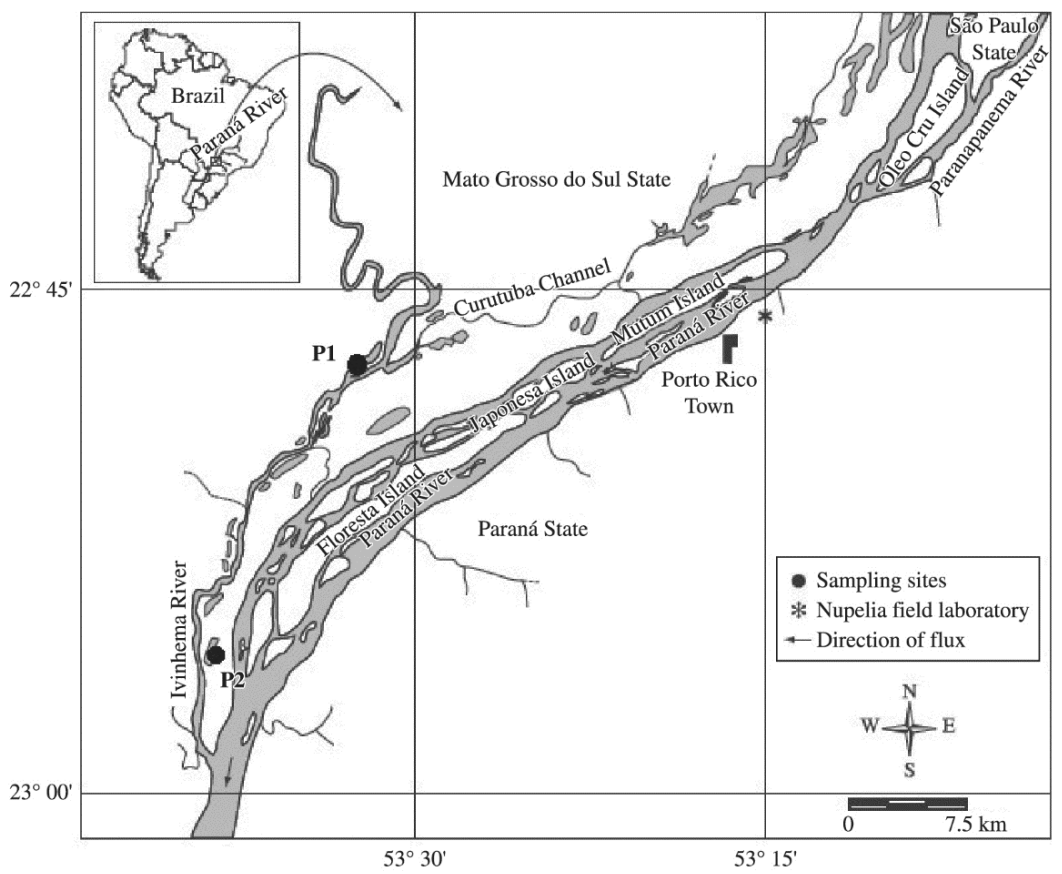

Figure 1. Location of the sampling sites in the Upper Paraná River floodplain, Brazil. P1: Finado Raimundo Lake and P2: Pintado Lake. 
of the lakes is colonized by woods, where the predominant genus is Cecropia, shrubs and Polygnum and also with areas occupied by macrophytes, with Eichhornia azurea being the most abundant species. The depth of these lakes ranges from 3 to 6 meters.

\subsection{Sampling and frequency of collections}

The vertical distribution of zooplankton organisms and predators (fish larvae) was examined in the limnetic region (surface and bottom) of the sites $\mathrm{P} 1$ and $\mathrm{P} 2$ during the day $(12: 00 \mathrm{~h})$ and at night $(00: 00 \mathrm{~h})$ by monthly samplings from April 2008 to January 2009. The depth of the sampling points is 4 meters.

Zooplankton samplings were performed using a motorised pump to filter 200 litres of water per sample through a conical net (68- $\mu \mathrm{m}$ mesh size). The material collected was stored in labelled polyethylene vials, and fixed with $4 \%$ formaldehyde buffered with calcium carbonate. For sampling fish larvae it was used a conical-cylindrical plankton net with $0.5-\mathrm{mm}$ mesh size with a flowmeter attached to the mouth to obtain the volume of filtered water. The net was hauled using boats at low speed. Bottom collections were undertaken through a plankton net with the same mesh size and a flowmeter, attached to a metal sled. Individuals caught were anaesthetised with eugenol (4-allyl-2-methoxyphenol) and then fixed with $4 \%$ formaldehyde buffered with calcium carbonate. Concurrently to plankton samplings, water samples were taken using a $5 \mathrm{~L}$ Van Dorn bottle to determine abiotic variables - $\mathrm{pH}$, water temperature (expressed in ${ }^{\circ} \mathrm{C}$ ), electrical conductivity (expressed in $\mu \mathrm{S} / \mathrm{cm}$ ) and dissolved oxygen (expressed in $\mathrm{mg} / \mathrm{L}$ ) - using portable digital equipment.

\subsection{Laboratory analysis}

For the determination of zooplankton density, subsamples were taken with a Hensen-Stempell pipette $(2.5 \mathrm{~mL})$, and at least 50 individuals of rotifers, cladocerans, and young forms (nauplii and copepodids) and adults of copepods were counted in Sedgewick-Rafter chambers under an optical microscope. The count of organisms was based on the methodology of Bottrell et al. (1976), by setting three subsamples for each sample collected. Samples with a low number of individuals were counted entirely. The total density was expressed in ind. $/ \mathrm{m}^{3}$. For species identification, we used specific literature for each group.

For the analysis of ichthyoplankton, fish larvae were separated from the rest of the plankton, with the aid of a stereoscopic microscope and Bogorov chamber at a magnification of $10 \times$. Larvae were identified considering all morphometric characteristics according to Nakatani et al. (2001). Subsequently, data of larval density were standardised to a volume of $10 \mathrm{~m}^{3}$ of filtered water, according to Nakataniet al.(2001).

\subsection{Statistical analysis}

The possible influence of environmental parameters $(\mathrm{pH}$, temperature, dissolved oxygen and electrical conductivity) on zooplankton and ichthyoplankton communities was evaluated by Pearson correlations. This analysis was run using Statistica ${ }^{\mathrm{TM}} 7.1$ (Statsoft Inc., 2005). The significance level was set at $\mathrm{p}<0.05$.

For the analysis of the vertical distribution of the collected organisms, the mean depth distribution during the day and night for each population of zooplankton and of fish larvae was calculated according to the Equation 1 of weighted mean depth (WMD) of Frost and Bollens (1992):

$W M D=(\Sigma n i d i) /(\Sigma n i)$

Where $n i$ is the density (individuals per $\mathrm{m}^{3}$ ) of the population $i$ and $d i$ is the depth of the sample $i$, which is considered as the midpoint of each depth layer. The amplitude of vertical migration of organisms was determined by the difference between the mean depth of the organism $i$ during the day and night.

As a criterion for determining the DVM behaviour, the mean differences of WMD between day and night of the populations distribution were tested using the two-tailed t-test. It is considered DVM when the difference between means of WMD day and night is significant $(p<0.05)$. The migration amplitude $(\Delta \mathrm{Z})$ was determined by the difference between the WMD day and night, with positive values indicating normal DVM and negative values indicating reverse DVM.

In order to understand the variation of populations of predator (fish larvae) and prey (zooplankton) in the water column, the overlap index was calculated using the Equation 2 described by Williamson and Stoeckel (1990):

$O i j=\sum_{z=1}^{m}(N j z n i z) m / \sum_{z=1}^{m}(N j z) \cdot \sum_{z=1}^{m}(n i z)$

where $z$ is the depth, $m$ is the number of sampled depths, $N j z$ is the density of the predator $i$ and niz is the density of the prey $i$. Values of $O i j$ vary from zero (without overlap) to the upper limit (complete overlap), limited to the number of sampled depths. If predator and prey are evenly distributed in the water column, $O i j=1$, values $<1$ indicate some degree of segregation between species studied, and values $>1$ indicate some degree of aggregation between species studied in any layer of the water column.

\section{Results}

\subsection{Environmental variables}

In general, during the study period there was a slight variation of abiotic values between the surface and the bottom of the sites. At site P1, the temperature of the water column had the highest difference between surface and bottom in November $\left(3.9^{\circ} \mathrm{C}\right)$, while at P2 the highest gradient between layers was registered in September and October $\left(1.8^{\circ} \mathrm{C}\right)$ (Figures 2a-b). The dissolved oxygen at the sites $\mathrm{P} 1$ and $\mathrm{P} 2$ presented the highest gradient in May with $1.39 \mathrm{mg} . \mathrm{L}^{-1}$ and $2.8 \mathrm{mg} . \mathrm{L}^{-1}$, respectively (Figures $2 \mathrm{c}-\mathrm{d}$ ). Values of electrical conductivity showed a small variation between surface and bottom in the sampled sites: in P1 the highest difference between strata was detected in September $(4.9 \mu \mathrm{S} / \mathrm{cm})$, whereas for P2 it was observed in May $(11.8 \mu \mathrm{S} / \mathrm{cm})$ (Figures $2 \mathrm{e}-\mathrm{f})$. For the $\mathrm{pH}$ there was 
no stratification between the surface and bottom of the sites (Figures 2g-h).

\subsection{Densities of fish larvae and zooplankton in the lakes}

The communities examined in this study exhibited, in general, significantly ( $p<0.05$, two-tailed t-test) higher densities at the site P1. Fish larvae in this site showed higher density in October (159.6 ind./10m ${ }^{3}$ ), and at the site $\mathrm{P} 2$, the highest density was observed in January (48.3 ind. $\left./ 10 \mathrm{~m}^{3}\right)$, without catch of larvae in July and August in both sites (Figure 3a). In relation to zooplankton organisms, rotifers at the site P1 exhibited higher density in July $\left(243 \times 10^{3}\right.$ ind. $\left./ \mathrm{m}^{3}\right)$, while for P2, the highest density was found in April $\left(45.6 \times 10^{3}\right.$ ind.$\left./ \mathrm{m}^{3}\right)$ (Figure $3 \mathrm{~b}$ ). Cladocerans at $\mathrm{P} 1$ showed the highest density in December $\left(49.0 \times 10^{3}\right.$ ind. $\left./ \mathrm{m}^{3}\right)$, and at $\mathrm{P} 2$, in September $\left(27.1 \times 10^{3}\right.$ ind.$\left./ \mathrm{m}^{3}\right)$ (Figure $\left.3 \mathrm{c}\right)$. Copepods at the site $\mathrm{P} 1 \mathrm{had}$ the highest density in December $\left(139.5 \times 10^{3}\right.$ ind. $\left./ \mathrm{m}^{3}\right)$, and at P2, in September $\left(721.1 \times 10^{3}\right.$ ind. $\left./ \mathrm{m}^{3}\right)$ (Figure $3 \mathrm{~d}$ ).

Generally, it was possible to distinguish a clear heterogeneous distribution of fish larvae in the water column, especially at $\mathrm{P} 1$, where the higher abundances during the day were observed in the bottom, and during the night in the surface (Figure 4). The zooplankton community had no clear seasonal pattern in distribution in the water column, for both lakes (Figure 4).
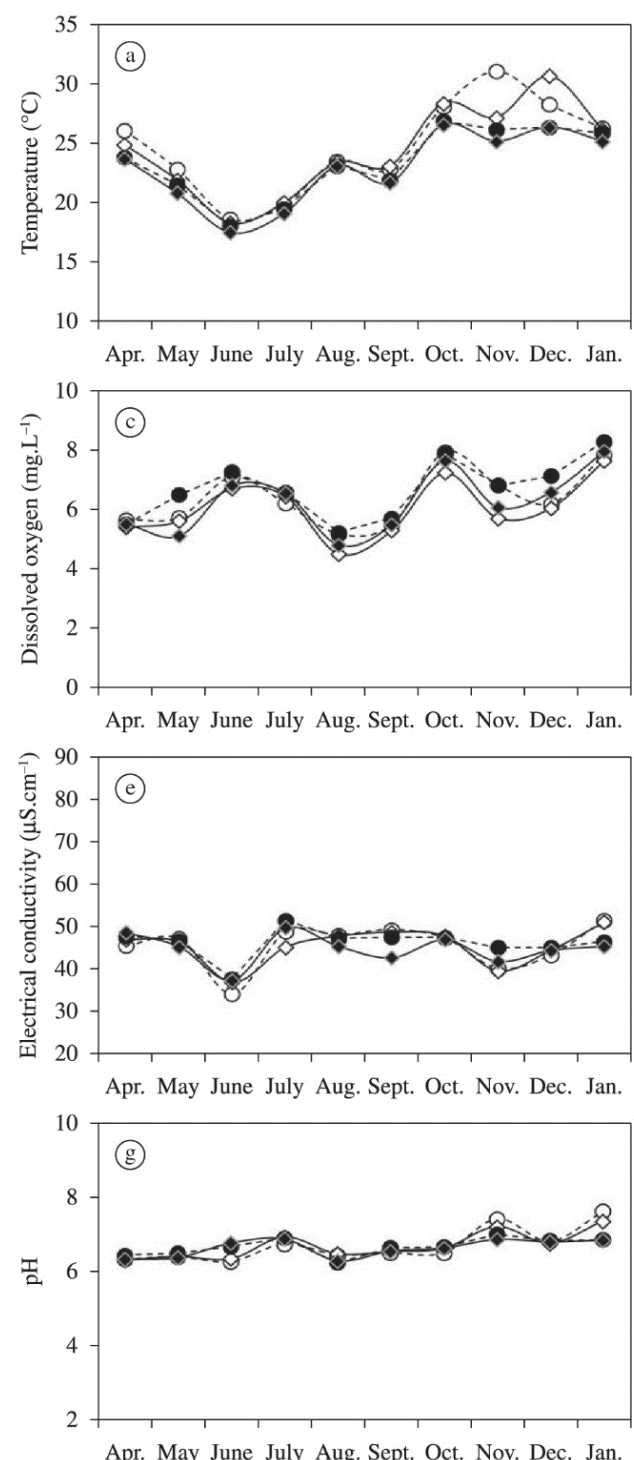
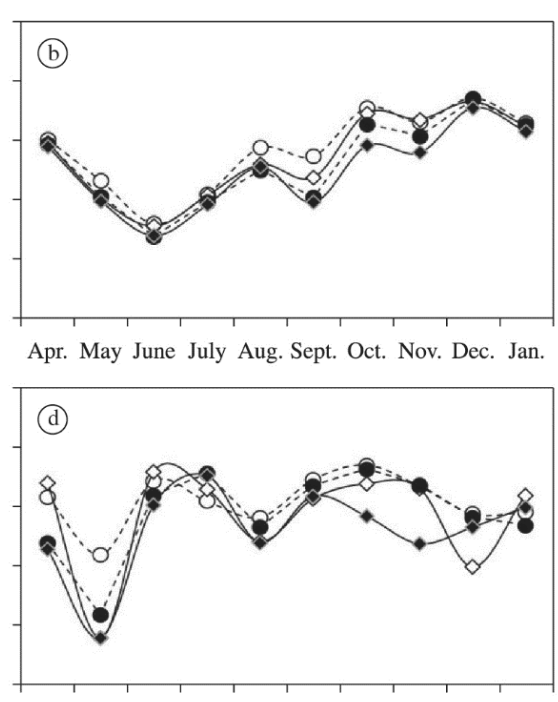

Apr. May June July Aug. Sept. Oct. Nov. Dec. Jan.
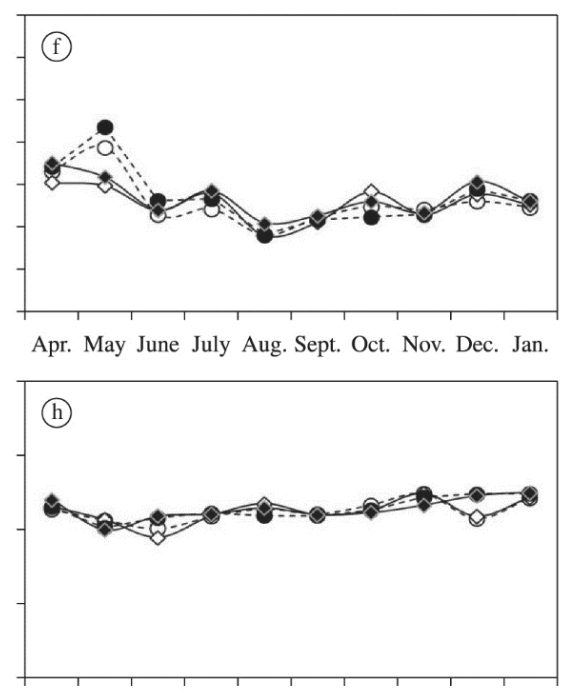

Apr. May June July Aug. Sept. Oct. Nov. Dec. Jan.

O Surface - Day $\diamond$ Bottom - Day $\bullet$ Surface - Night $\diamond$ Bottom - Night

Figure 2. Variation of temperature, dissolved oxygen, electrical conductivity and $\mathrm{pH}$ during the day and night at the surface and on the bottom of sites P1 (a, c, e and $\mathbf{g}$ ) and P2 (b, d, f and h) between April 2008 and January 2009. 

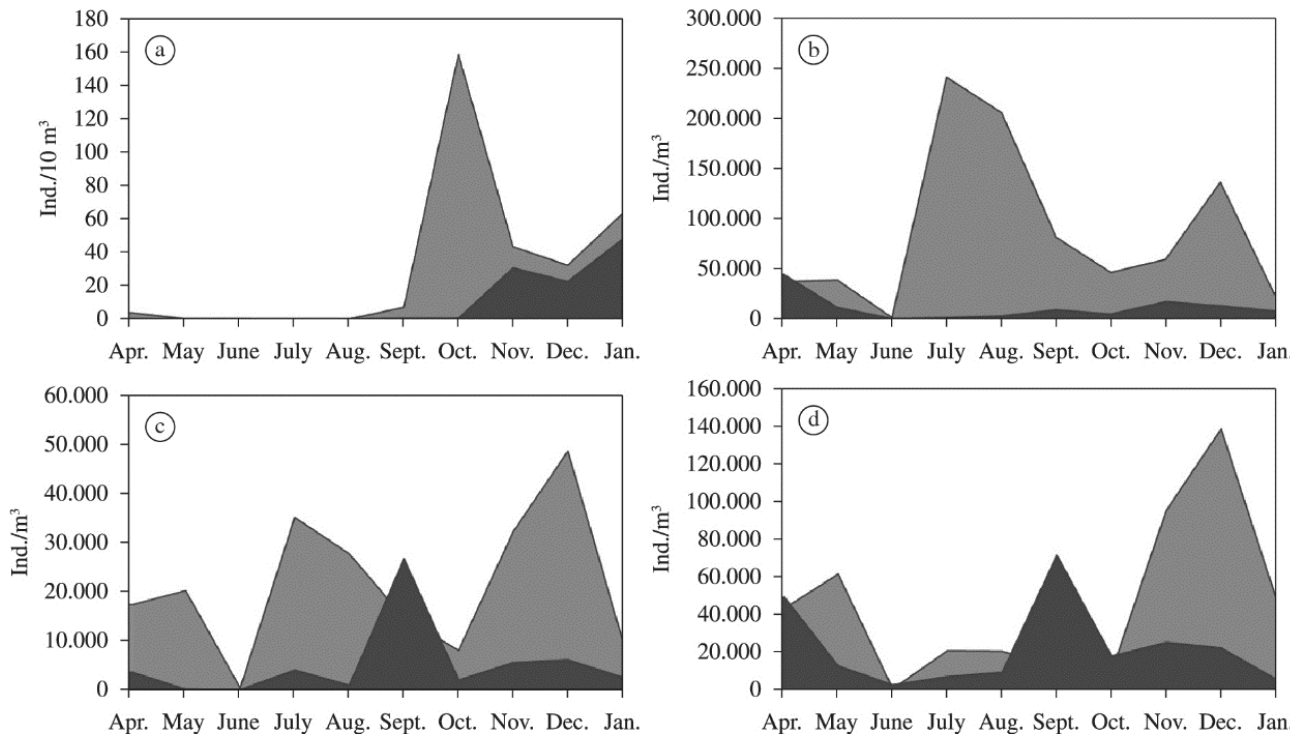

$\square \mathrm{P} 1 \quad \square \mathrm{P} 2$

Figure 3. Monthly density of fish larvae (a), rotifer (b), cladoceran (c) and copepod (d) at sites P1 and P2 between April 2008 and January 2009. Note the differences among scales.

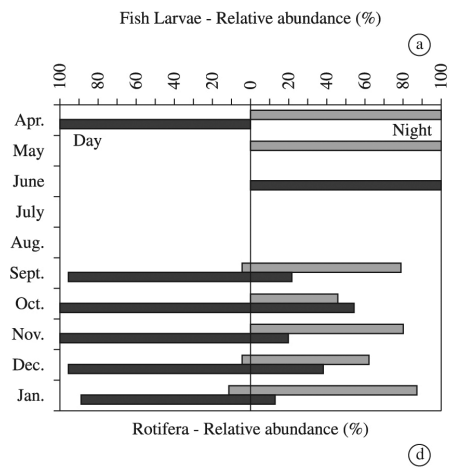

(a) Fish Larvae - Relative abundance (\%)

(b) Rotifera - Relative abundance (\%)
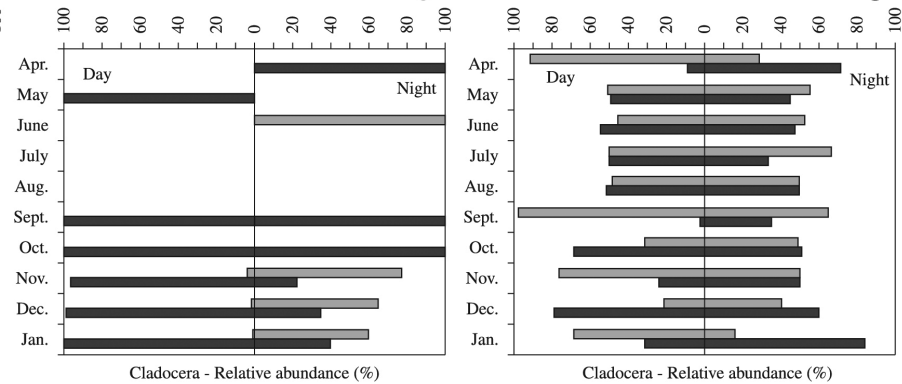

Cladocera - Relative abundance (\%)
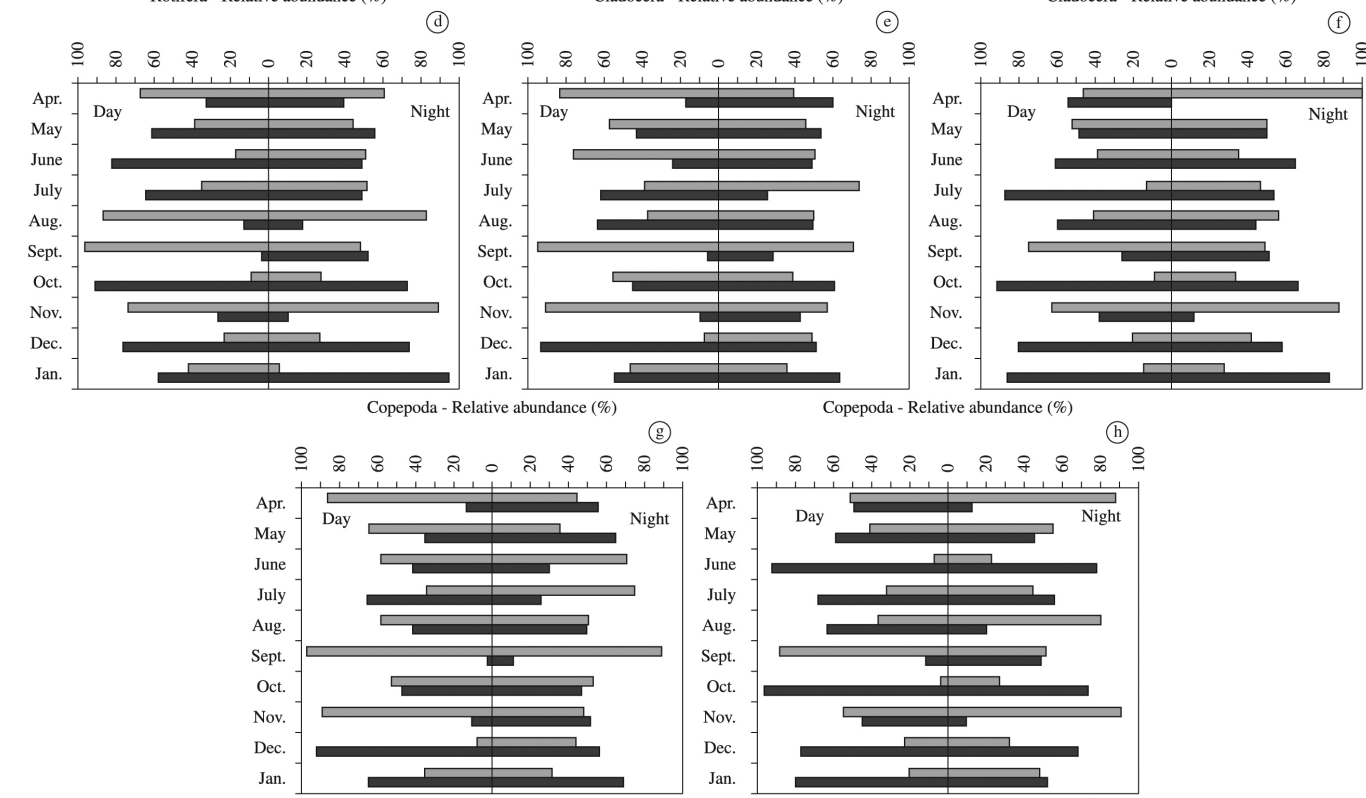

Copepoda - Relative abundance $(\%)$

(b)

Figure 4. Monthly relative abundance day-night and surface (gray bars) - bottom (black bars) of fish larvae, rotifer, cladoceran and copepod at sites P1 (a, c, e and $\mathbf{g}$ ) and P2 (b, d, f and $\mathbf{h})$ between April 2008 and January 2009. 


\subsection{Diel vertical migration patterns and seasonal changes in the weighted mean depth of zooplankton distribution}

Changes in patterns of vertical distribution of zooplankton organisms in the sites P1 and P2 are clearly discernible in some sampling months. Significant differences ( $\mathrm{p}<0.05$, twotailed t-test) were found in the diel distribution for rotifers at the site P1 in April, July, September, October, November, December and January, showing that these organisms migrated along the water column. In the other months there were no significant differences between day and night, indicating the reduction or even the absence of vertical migration. At P2, significant differences in the diel distribution of rotifers were registered in June, July, September, October, November and January. The migration amplitude for rotifers at the site P1 varied between 0 and $2.4 \mathrm{~m}$, whilst at the site $\mathrm{P} 2$, from 0 and $1.9 \mathrm{~m}$. Cladocerans showed significant differences in the diel distribution at the site $\mathrm{P} 1$ in almost all study months, except for January. At P2, there were significant differences in diel distribution of cladocerans in April, July, August, September, October, November and December. The migration amplitude for cladocerans at the site $\mathrm{P} 1$ ranged from 0.3 to $1.7 \mathrm{~m}$, and in the P2, from 0 to $2.1 \mathrm{~m}$. Regarding the copepods, they had significant differences in diel distribution at the site P1 in April, May, July, November and December, whereas at the $\mathrm{P} 2$, significant differences in diel distribution occurred in most months, except in December. The migration amplitude of these microcrustaceans at $P 1$ varied between 0 and $1.6 \mathrm{~m}$, and at P2, between 0.7 and $1.7 \mathrm{~m}$ (Figure 5).
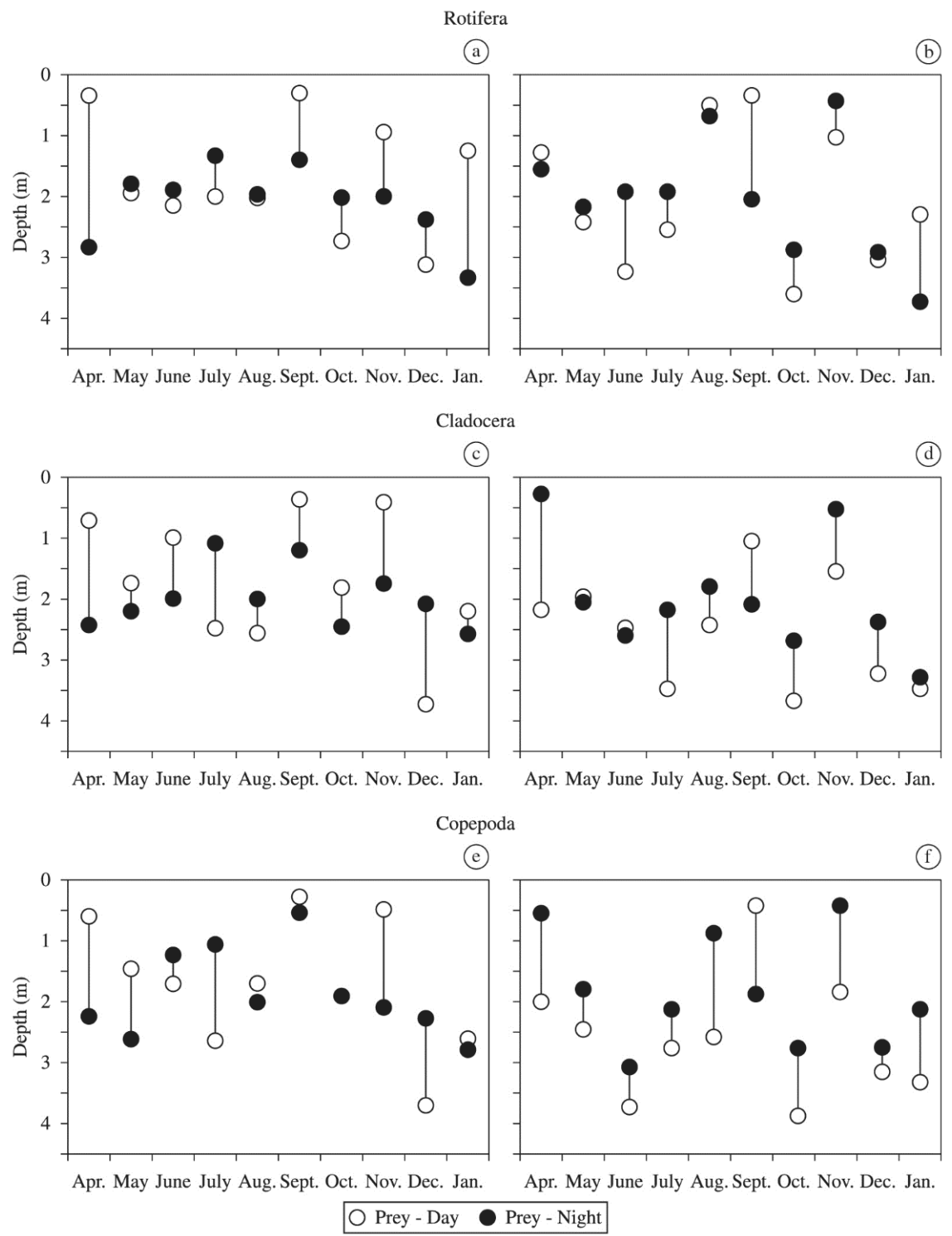

Figure 5. Weighted mean depth (WMD) of zooplankton (rotifer, cladoceran and copepod) distribution during the day and night at sites P1 (a, c, and e) and P2 (b, d, and f) between April 2008 and January 2009 (bars, migration amplitude). 


\subsection{Relationship between densities of fish larvae and zooplankton with environmental variables}

The correlation between density of larvae and of zooplankton groups with environmental variables showed three positive and one negative significant correlations in the site P1: between the density of fish larvae with temperature $\left({ }^{\circ} \mathrm{C}\right)(\mathrm{r}=0.44$ and $\mathrm{p}=0.038)$ and with dissolved oxygen $\left(\mathrm{mg} . \mathrm{L}^{-1}\right)(\mathrm{r}=0.49$ and $\mathrm{p}=0.017)$; between density of rotifers with dissolved oxygen $\left(\mathrm{mg} . \mathrm{L}^{-1}\right)(\mathrm{r}=-0.31$ and $\mathrm{p}=0.046)$; and between density of copepods with temperature $\left({ }^{\circ} \mathrm{C}\right)$ $(\mathrm{r}=0.48$ and $\mathrm{p}=0.001)$. For the site $\mathrm{P} 2$, there was a positive significant correlation between density of fish larvae with $\mathrm{pH}(\mathrm{r}=0.52$ and $\mathrm{p}=0.020)$. For the other results, there were no significant correlations recorded between densities of fish larvae and zooplankton groups with environmental variables (Table 1).

\subsection{The effect of fish larvae on zooplankton vertical distribution}

The weighted mean depth (WMD) of zooplankton and fish larvae distribution during the day and night are shown in Figure 6. In the site P1, fish larvae exhibited normal diel vertical migration in all months when catches were recorded, i.e. they remained in deeper strata during the day and came up to upper strata night. In the site P2, larvae exhibited normal DVM between November and January, but in September larvae remained in the lower layer during the day and night. For the other months it
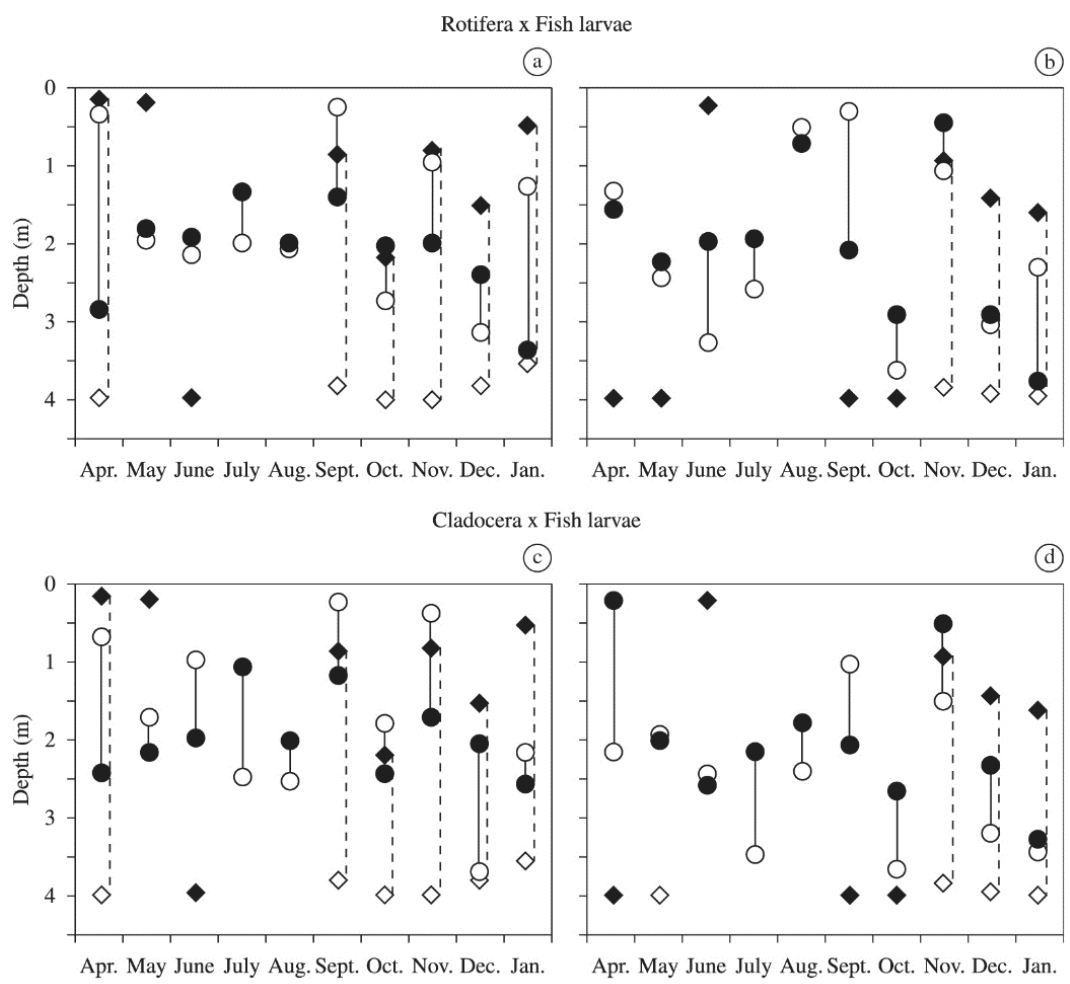

Copepoda x Fish larvae

(e)

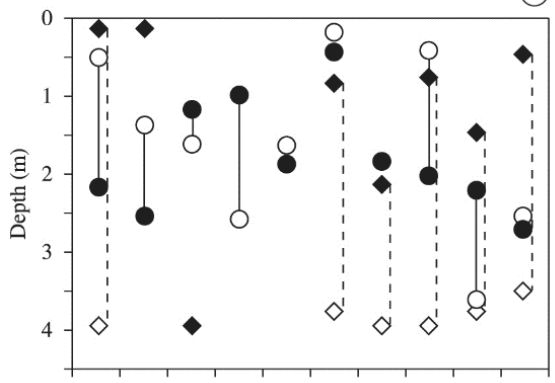

Apr. May June July Aug. Sept. Oct. Nov. Dec. Jan.

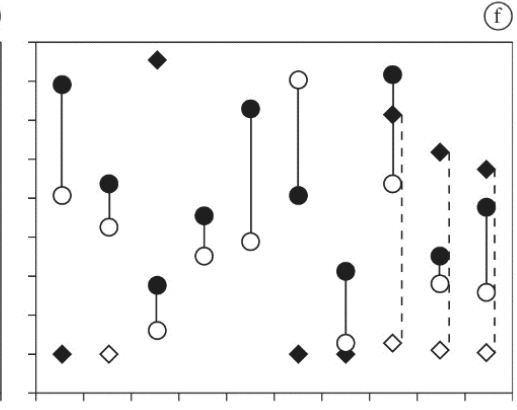

Apr. May June July Aug. Sept. Oct. Nov. Dec. Jan.

$\bigcirc$ Prey - Day $\diamond$ Predator - Day $\bigcirc$ Prey - Night $\diamond$ Predator - Night

Figure 6. Weighted mean depth (WMD) of predator (fish larvae) and prey (rotifer, cladoceran and copepod) at sites P1 (a, c, and e) and P2 (b, d, and f) between April 2008 and January 2009 (bars, migration amplitude). 
Table 1. Pearson Correlation between environmental variables and density of fish larvae, rotifer, cladoceran and copepod at sites P1 and P2 (bold values indicate significant correlation; $\mathrm{p}<0.05$ ).

\begin{tabular}{ccccc}
\hline Environmental & \multicolumn{4}{c}{ Finado Raimundo Lake } \\
\hline Variables & Fish larvae & Rotifera & Cladocera & Copepoda \\
\hline Temperature $\left({ }^{\circ} \mathrm{C}\right)$ & $\mathbf{0 . 4 4}$ & -0.09 & 0.30 & $\mathbf{0 . 4 8}$ \\
Dissolved oxygen $\left(\mathrm{mg} . \mathrm{L}^{-1}\right)$ & $\mathbf{0 . 4 9}$ & $-\mathbf{0 . 3 1}$ & -0.18 & -0.01 \\
Electrical conductivity $\left(\mu \mathrm{S} . \mathrm{cm}^{-1}\right)$ & -0.02 & 0.11 & -0.00 & -0.06 \\
$\mathrm{pH}$ & 0.03 & -0.00 & 0.15 & 0.19 \\
\hline Environmental & Fish larvae & Rotifera & Cladocera & Copepoda \\
\hline Variables & 0.34 & 0.23 & -0.09 & 0.06 \\
Temperature $\left({ }^{\circ} \mathrm{C}\right)$ & 0.22 & 0.08 & 0.22 & 0.23 \\
Dissolved oxygen $\left(\mathrm{mg} . \mathrm{L}^{-1}\right)$ & -0.13 & 0.25 & -0.16 & 0.00 \\
\hline Electrical conductivity $\left(\mu \mathrm{S} . \mathrm{cm}^{-1}\right)$ & $\mathbf{0 . 5 2}$ & 0.17 & 0.02 & 0.07 \\
\hline
\end{tabular}

was not possible to detect the DVM, since larvae were caught only in one stratum. The migration amplitude of fish larvae at the $\mathrm{P} 1$ varied between 1.8 and $3.9 \mathrm{~m}$, while at P2, between 0.1 and $2.9 \mathrm{~m}$ (Figure 6). The spatial overlap analysis of zooplankton groups with fish larvae indicated that at night the mean values of overlap in the site P1 were 0.37 rotifers, 0.37 cladocerans and 0.38 copepods, while during the day were 0.45 rotifers, 0.49 cladocerans and 0.46 copepods. The spatial overlap analysis of zooplankton groups with fish larvae at the site P2 showed that at night the mean values were 0.53 rotifers, 0.61 cladocerans and 0.61 copepods, whereas the mean values during the day were 0.53 rotifers, 0.45 cladocerans and 0.46 copepods. The analysis of spatial overlap indicated that the zooplankton organisms substantially reduced the overlap with fish larvae.

\section{Discussion}

Data about vertical distribution of ichthyoplankton and zooplankton in the lakes Finado Raimundo and Pintado provide evidence that these communities perform diel vertical migration, based on the differences found in the vertical distribution between day and night. Physical and chemical characteristics of the studied water bodies exhibited no considerable variation between the surface and bottom, possibly due to the small depth of the lakes (maximum depth of $6 \mathrm{~m}$ ). Therefore these characteristics have do not explain the stratification of the analysed communities. This probably explains that the lakes are subjected to rapid cooling and heating processes and continuous mixing by wind action, which prevents the formation of vertical stratifications.

In general, fish larvae exhibited a clear pattern of diel vertical distribution in the water column. For both lakes Finado Raimundo and Pintado it was observed a normal DVM phenomenon, with the larvae remaining in upper strata (surface) night, and migrating toward deeper and darker layers (bottom) during the day. The most accepted idea to explain the causes for DVM in freshwater fish is the light cycle, comprising the of light-dark cycle or the day-night cycle, which are separated by brief crepuscular periods (dusk, dawn) when the light changes rapidly
(Mehner, 2012). There is general consensus that the decline in lighting at dusk stimulates the rise of several fish genera in the water column, whereas the increasing illumination at dawn induces the descent to the darker layers (Probst and Eckmann, 2009).

The zooplankton community showed variations in its responses (in terms of DVM) to predation pressure exerted by fish larvae in the two lakes. In the presence of predators (fish larvae), especially in the Finado Raimundo Lake, rotifers have shown a reverse DVM. The hypothesis of avoidance of predation has also been used to explain the reverse DVM; this behaviour is the result of the avoidance of predation by predators, which, in turn, perform regular DVM (Ohman et al., 1983), and this behaviour was found in fish larvae of the present study. Some field studies (Stich and Lampert, 1981; Ohman et al., 1983) suggest that rotifers can present well-defined movements on a small scale (less than 1 meter) over a period of several hours, which are significantly and negatively correlated with the diel movement of predators. Williamson (1993) observed that some rotifers substantially reduced the risk of predation through diel vertical migration. Gilbert and Hampton (2001) showed that Polyarthra remata Skorikov, 1986 displays reverse DVM, remaining on the surface during the day and migrating to deeper layers at night to avoid predation.

The wide variation of responses from rotifers to predators over the months and between lakes studies was mainly due to the great variety of species of this group, where each species may have a specific pattern of distribution in the water column. González (1998) registered a species-specific migratory pattern in rotifers in the presence of predators, for example: Kellicottia longispina Ahlstrom, 1983 and Polyarthra sp. showed a clear pattern of DVM, while Keratella cochlearis (Gosse, 1851) showed no migratory behaviour. It was also possible to verify the reduction in the amplitude of vertical migration of rotifers in months when predators were scarce or absent. Iacobuzio and Tiberti (2011) observed that the absence of predator fish induces the reduction or even the elimination of the 
migratory behaviour of some zooplankton groups, while in the presence of fish the DVM is observed.

In many pelagic communities the predation pressure may come from distinct kind of organisms, such as planktivorous fish and invertebrate predators. The presence of multiple predators can result in a more complex migratory response of zooplankton prey more, since reducing the risk of predation from a certain predator may simultaneously increase the risk from another predator (Nesbitt et al., 1996). Williamson (1993) highlights that the spatial overlap may play a key role in determining which prey will be consumed by predators.

Regarding the microcrustaceans, cladocerans showed a distinct behaviour between the lakes. In the Finado Raimundo Lake the most frequent behaviour was the reverse DVM, while in the Pintado Lake, the clearest pattern was the normal DVM. The DVM in cladocerans has been widely discussed. Several studies have already been conducted on this group, in particular those of Matsumura-Tundisi et al. (1984) and Lansac-Tôha et al. (1995). In these studies, the vertical distribution of cladocerans was mainly explained according to the oxygen and temperature. However, in the present study, abiotic factors such as oxygen could not explain the vertical distribution of zooplanktonic organisms given the small depth of the lakes without clear stratification. A similar reverse DVM behaviour in cladocerans was found by Ghidini and Santos-Silva (2011) in lakes where cladocerans had a reverse migratory behaviour during certain periods of the year due to the presence of predators.

Copepods in turn exhibited DVM in almost all months, alternating periods with reverse and normal migratory behaviour. The variation in the migration amplitude can be partially described because its density consists mostly of immature (nauplii and copepodids). Studies like those of Bezerra-Neto and Pinto-Coelho (2007) demonstrated ontogenetic differences in the distribution of Thermocyclops inversus (Kiefer, 1936), where nauplii hardly exhibited migratory behaviour, while adults and copepodids exhibited this behaviour. Such differences have generally been attributed to large individuals, which being more conspicuous and, therefore more susceptible to visual predators, migrates to avoid being predated (Neill, 1990). Studies such as Makrakis et al. $(2005,2008)$ analysing the diet of fish larvae have detected that the most abundant food item in the digestive tract of fish larvae were microcrustaceans (cladocerans and copepods).

In the present study, the Pearson correlation showed only two significant relationships between zooplankton organisms (rotifers and copepods) with abiotic variables. The absence of correlation between the distribution of zooplankton organisms and physical and chemical parameters is frequent in natural systems (Ghidini and Santos-Silva, 2011), especially in floodplains environments. In general, more than one factor influences the composition and distribution of zooplankton organisms. For fish larvae, this analysis indicated that densities have been more significantly influenced by temperature, oxygen and $\mathrm{pH}$. According to the observations of Baumgartner et al. (2008), larvae of different fish species exhibited different relationships with abiotic variables. This probably explains the distinct relationships of fish larvae with abiotic factors between the lakes, probably related to the significant difference between densities of fish larvae in the lakes.

In summary, it was observed that in the Finado Raimundo and Pintado lakes, rotifers exhibited reverse DVM in most months, for microcrustacenas (cladocerans and copepods) the normal DVM was evident only in the Pintado Lake, whereas the predators (fish larvae) exhibited a clear normal DVM in both lakes. This study showed that the spatial distribution of zooplankton organisms may be associated with the distribution of ichthyoplankton, and that the diel vertical migration of the zooplankton was important in reducing the spatial overlap with predators.

\section{Acknowledgements}

Authors thank the Núcleo de Pesquisas em Limnologia, Ictiologia e Aquicultura of the State University of Maringá for the logistic support to conduct the samplings and for providing the infrastructure to develop this work, and the National Council for Scientific and Technological Development for funding the study and providing a master's scholarship to the first author (process 552084/2010-7- CNPq, $\mathrm{MCT} / \mathrm{CNPq}$ number 70/2009).

\section{References}

BAUMGARTNER, G., NAKATANI, K., GOMES, LC., BIALETZKI, A., SANCHES, PV. and MAKRAKIS., 2008. Fish larvae from the upper Paraná River: Do abiotic factors affect larval density? Neotropical Ichthyology, vol. 6, no. 4, p. 551-558. http://dx.doi. org/10.1590/S1679-62252008000400002.

BEZERRA-NETO, JF. and PINTO-COELHO, RM., 2007. Diel vertical migration of the copepod Thermocyclops inversus (Kiefer, 1936) in a tropical reservoir: the role of oxygen and the spatial overlap with Chaoborus. Aquatic Ecology, vol. 41, no. 4, p. 535545. http://dx.doi.org/10.1007/s10452-007-9119-x.

BOTTRELL, HH., DUNCAN, A., GLIWICZ, ZM., GRYGIEREK, E., HERZIG, A., HILBRICHT-LLKOWSKA, A., KURAZAWA, H., LARSSON, P. and WEGLENSKA, TA., 1976. Review of some problems in zooplankton production studies. Journal of Zoology, vol. 24, p. 419-456.

CUSHING, DH., 1975. Marine Ecology and Fisheries. Cambridge: Cambridge University Press. 278 p.

DODSON, SI., 1988. The ecological role of chemical stimuli for the zooplankton: predator-avoidance behavior in Daphnia. Limnology and Oceanography, vol. 33, no. 6part2, p. 1431-1439. http:// dx.doi.org/10.4319/1o.1988.33.6_part_2.1431.

FROST, BW. and BOLLENS, SM., 1992. Variability of diel vertical migration in the marine planktonic copepod Pseudocalanus newmani in relation to its predators. Canadian Journal of Fisheries and Aquatic Sciences, vol. 49, no. 6, p. 1137-1141. http://dx.doi. org/10.1139/f92-126.

GHIDINI, AR. and SANTOS-SILVA, EN., 2011. Composition, species richness and patterns of nycthemeral vertical distribution of planktonic cladocereans in a black water Amazonian lake. 
Nauplius, vol. 19, no. 2, p. 109-122. http://dx.doi.org/10.1590/ S0104-64972011000200002.

GILBERT, JJ. and HAMPTON, SE., 2001. Diel vertical migrations of zooplankton in a shallow, fishless pond: a possible avoidanceresponse cascade induced by notonectids. Freshwater Biology, vol. 46, no. 5, p. 611-621. http://dx.doi.org/10.1046/j.13652427.2001.00697.x.

GONZÁLEZ, MJ., 1998. Spatial segregation between rotifers and cladocerans mediated by Chaoborus. Hydrobiologia, vol. 387, p. 426-436.

HANSSON, L-A., BECARES, E., FERNÁNDEZ-ALÁEZ, M., FERNÁNDEZ-ALÁEZ, C., KAIRESALO, T., MIRACLE, MR., ROMO, S., STEPHEN, D., VAKKILAINEN, K., VAN DE BUND, W., VAN DONK, E., BALAYLA, D. and MOSS, B., 2007a. Relaxed circadian rhythm in zooplankton along a latitudinal gradient. Oikos, vol. 116, no. 4, p. 585-591. http:// dx.doi.org/10.1111/j.0030-1299.2007.15754.x.

HANSSON, LA., HYLANDER, S. and SOMMARUGA, R., 2007b. Escape from UV threats in zooplankton: a cocktail of behavior and protective pigmentation. Ecology, vol. 88, no. 8, p. 1932-1939. http://dx.doi.org/10.1890/06-2038.1. PMid:17824423

IACOBUZIO, R. and TIBERTI, R., 2011. Cloud cover does not clearly affect the diurnal vertical distribution of crustacean zooplankton in naturally fishless alpine lakes. Plankton and Benthos Research, vol. 6, no. 4, p. 210-214. http://dx.doi. org/10.3800/pbr.6.210.

LANSAC-TÔHA, FA., THOMAZ, SM., LIMA, AF., ROBERTO, MC. and GARCIA, AP., 1995. Vertical distribution of some planktonic crustaceans in a varzea lake (Lake Pousada das Garças) of the floodplain of hight River Parana, MS, Brazil. International Journal of Ecology and Environmental Sciences, vol. 21, p. 67-78.

MAKRAKIS, MC., NAKATANI, K., BIALETZKI, A., SANCHES, PV., BAUMGARTNER, G. and GOMES, LC., 2005. Ontogenetic shifts in digestive tract morphology and diet of fish larvae of the Itaipu Reservoir, Brazil. Environmental Biology of Fishes, vol. 72, no. 1, p. 99-107. http://dx.doi.org/10.1007/s10641-004-6596-9.

MAKRAKIS, MC., NAKATANI, K., BIALETZKI, A., GOMES, LC., SANCHES, PV. and BAUMGARTNER, G., 2008. Relationship between gape size and feeding selectivity of fish larvae from a Neotropical reservoir. Journal of Fish Biology, vol. 72, no. 7, p. 1690-1707. http://dx.doi.org/10.1111/j.1095-8649.2008.01845.x.

MANETTA, GI., BIALETZKI, A., MARTINELLI, LA. and BENEDITO, E., 2011. Variability in the trophic position of larval fishes in the upper Paraná floodplain based on $\delta 15 \mathrm{~N}$. Anais $d a$ Academia Brasileira de Ciencias, vol. 83, no. 2, p. 567-574. http:// dx.doi.org/10.1590/S0001-37652011000200016. PMid:21670879

MATSUMURA-TUNDISI, T., TUNDISI, SG. and TAVARES, LS., 1984. Diel migration and vertical distribution of Cladocera in Lake D. Helvécio. Hydrobiologia, vol. 113, no. 1, p. 299-306. http://dx.doi.org/10.1007/BF00026616.

MEHNER, T., 2012. Diel vertical migration of freshwater fishes - proximate triggers, ultimate causes and research perspectives. Freshwater Biology, vol. 57, no. 7, p. 1342-1359. http://dx.doi. org/10.1111/j.1365-2427.2012.02811.x.

NAKATANI, K.,AGOSTINHO, AA.,BAUMGARTNER, G.,BIALETZKI, A.,SANCHES, PV.,MAKRAKIS, MC. and PAVANELLI, CS.,2001. Ovos e larvas de peixe de água doce: desenvolvimento e manual de identificação. Maringá: Eduem. 378 p.
NEILL, WE., 1990. Induced vertical migration in copepods as a defense against invertebrate predation. Nature, vol. 345, no. 6275, p. 524-526. http://dx.doi.org/10.1038/345524a0.

NESBITT, LM., RIESSEN, HP. and RAMCHARAN, CW., 1996. Opposing predation pressures and induced vertical migration responses in Daphnia. Limnology and Oceanography, vol. 41, no. 6, p. 1306-1311. http://dx.doi.org/10.4319/1o.1996.41.6.1306.

OHMAN, MD., FROST, BW. and COHEN, EB., 1983. Reverse diel vertical migration: an escape from invertebrate predators. Science, vol. 220, no. 4604, p. 1404-1407. http://dx.doi.org/10.1126/ science.220.4604.1404. PMid:17730658

PEARRE JUNIOR, S., 2003. Eat and run? The hunger/satiation hypothesis in vertical migration: history, evidence and consequences. Biological Reviews of the Cambridge Philosophical Society, vol. 78, no. 1, p. 1-79. http://dx.doi.org/10.1017/S146479310200595X. PMid:12620061

PROBST, WN. and ECKMANN, R., 2009. The influence of light on the diel vertical migration of young-of-the-year burbot Lota lota in Lake Constance. Journal of Fish Biology, vol. 74, no. 1, p. 150-166. http://dx.doi.org/10.1111/j.1095-8649.2008.02120.x. PMid:20735530

RINGELBERG, J., 2010. Diel vertical migration of zooplankton in lakes and oceans. Dordrecht: Springer. $356 \mathrm{p}$.

SOARES, CM., 2003. Interações tróficas de quatro espécies de peixes nativos em fase de desenvolvimento inicial: alterações nas comunidades, alimentação e tamanho da boca. Maringá: Universidade Estadual de Maringá. Doctoral thesis in Ecology of Continental Aquatic Environments.

SOUZA FILHO, EE. and STEVAUX, JC. 2004. Geology and geomorphology of the Baía-Curutuba-Ivinheima river complex. In THOMAZ, SM., AGOSTINHO, AA. and HAHN, NS. (Eds.). The Upper Paraná River and its floodplain: physical aspects, ecology and conservation. Leiden: Backhuys Publishers. p. 1-29.

Statsoft Inc., 2005. STATISTICA for Windows (data analysis software system). Version 7.1.

STICH, HB. and LAMPERT, W., 1981. Predator evasion as an explanation of diurnal vertical migration by zooplankton. Nature, vol. 293, no. 5831, p. 396-398. http://dx.doi.org/10.1038/293396a0.

TOMM, I., POZZOBON, MGG., DALLA-COSTA, MLSR. and LANSAC-TÔHA, FA., 1992. Distribuição vertical nictemeral de crustáceos planctônicos em um braço do reservatório de ItaipuPR. Revista Unimar, vol. 14, p. 57-22.

WETZEL, RG., 2001. Limnology: lake and river ecosystems. San Diego: Academic Press. 1006 p.

WILLIAMSON, CE. and STOECKEL, ME., 1990. Estimating predation risk in zooplankton communities: the importance of vertical overlap. Hydrobiologia, vol. 198, no. 1, p. 125-131. http://dx.doi.org/10.1007/BF00048629.

WILLIAMSON, CE., 1993. Linking predation risk models with behavioral mechanisms: identifying population bottlenecks. Ecology, vol. 74, no. 2, p. 320-331. http://dx.doi.org/10.2307/1939295.

ZARET, TM. and SUFFERN, JS., 1976. Vertical migration in zooplankton as a predator avoidance mechanism. Limnology and Oceanography, vol. 21, no. 6, p. 804-813. http://dx.doi. org/10.4319/lo.1976.21.6.0804. 